\title{
Firm heterogeneity and wages in unionised labour markets: Theory and evidence*
}

\author{
Paulo Bastos $^{\dagger} \quad$ Natália P. Monteiro Odd Rune Straume $^{\S}$
}

April 2008

\begin{abstract}
In many countries wages are set in two stages, where industry-level collective bargaining is followed by firm-specific arrangements determining actual paid wages as a mark-up on the industry wage floor. What explains the wage set in each of these stages? In this paper we show that both the industry wage floor and the average wage cushion are systematically associated with the degree of firm heterogeneity in the industry: The former (latter) is negatively (positively) associated with the productivity spread. Furthermore, since the response of the wage floor dominates that of the wage cushion, workers in more heterogeneous industries tend to get lower actual paid wages. These conclusions are reached in a model of Cournot oligopoly with firm productivity heterogeneity and a two-tiered wage setting system. They are then confirmed by administrative data covering virtually all workers, firms and collective bargaining agreements of the Portuguese private sector for the period 1991-2000.
\end{abstract}

Keywords: Wage determination; Trade unions; Firm heterogeneity

Jel Classification: D21; J31; J51; L13

\footnotetext{
${ }^{*}$ We thank Miguel Portela and Jeffrey Wooldridge for valuable comments. The views expressed in this paper belong to the authors only and do not necessarily correspond to those of the European Commission.

${ }^{\dagger}$ ECFIN, European Commission. E-mail: paulo.bastos@ec.europa.eu.

${ }^{\ddagger}$ Department of Economics and NIPE, University of Minho. E-mail: n.monteiro@eeg.uminho.pt

${ }^{\S}$ Corresponding author. Department of Economics and NIPE, School of Economics and Management, University of Minho, Campus de Gualtar, 4710-057 Braga, Portugal. Email: o.r.straume@eeg.uminho.pt
} 


\section{Introduction}

In many European countries, wages are set in two stages. First, industry-level collective bargaining establishes a binding wage floor, common to all firms in the industry. At a second stage, firmspecific arrangements determine a mark-up on top of the central wage. Such a two-tiered wage setting system tends to originate a large difference between actual paid wages and the central wage floor, a phenomena typically referred to as the wage cushion or the wage drift. ${ }^{1}$

What explains the wage set in each of these stages? The key contribution of this paper is to show that both the industry wage floor and the average wage cushion are systematically associated with the degree of firm heterogeneity in the industry. The industry wage floor is negatively correlated, while the average wage cushion is positively correlated, with the productivity spread. The main intuition for these results is that in industries with more heterogeneous firms an industry-wide union has a rational incentive to impose a lower wage floor in order to preclude job losses in less productive firms. Greater firm heterogeneity and a lower wage floor, on the other hand, leave more room for firm-specific rent-sharing, thereby increasing the average wage cushion.

To formalise these arguments, we develop a model of Cournot oligopoly with firm productivity heterogeneity and a two-tiered wage setting system. At the outset, an industry-wide monopoly union sets a wage floor, common to all producers. At a second stage, firm-specific wages and employment are determined. To characterise wage determination at the local level, we adopt a general formulation of rent-sharing, which is consistent with different underlying mechanisms proposed in the literature to explain its existence - namely, firm-specific fair wage policies and local bargaining. When setting the wage floor at the outset of the game, the central union anticipates the implications of its actions for the determination of actual wages and employment at the second stage. The model yields clear and intuitive predictions about the effect of firm heterogeneity measured as a mean-preserving spread of labour productivities - on wage setting. Notably, for 'reasonable' parameter configurations, we find that more heterogeneity leads to a lower industry wage floor and a higher (average) wage cushion; since the former of these effects tends to dominate the latter, all else equal workers in more heterogeneous industries tend to get lower wages.

We then proceed by taking the model predictions to the data. With that aim, we exploit Quadros de Pessoal, an unusually comprehensive administrative worker-firm dataset that is particularly well suited for investigating this question. Quadros de Pessoal comprises information on virtually all workers, firms and collective bargaining agreements for the Portuguese private sector. It also allows

\footnotetext{
${ }^{1}$ Such a two-tiered wage setting process is prevalent in the Nordic countries (Calmfors, 1990; Holden, 1989, 1998), Germany (Hübler and Jirjahn, 2003), Italy (Ordine, 1995), Spain (Dolado et al, 1997), The Netherlands (Butter and Eppink, 2003) and Portugal (Cardoso and Portugal, 2005). Flanagan (1999) and OECD (2004) offer recent literature surveys. Following Cardoso and Portugal (2005), throughout this paper we will use the expression wage cushion to label the difference between actual wages and the union wage floor, noting however that the concept wage drift has also been frequently adopted in the literature to designate this phenomena.
} 
to distinguish, at the individual-level, between the industry wage floor and the wage cushion. Since there is a unique identifier for the collective agreement that covers each worker, it is possible to determine the exact set of firms that constitute the industry for collective bargaining purposes. Given that there is also information on the firm side, we are able to compute standard measures of firm productivity heterogeneity in each industry, and then test whether they are systematically associated with the industry wage floor and the average wage cushion (and hence with actual paid wages). The econometric results confirm our theoretical predictions.

This paper relates to several strands of existing research. There are some structural similarities between the model presented here and a relatively small literature on unionised labour markets with a two-tiered wage setting process. Inspired by the collective bargaining system of the Nordic countries, Holden (1998) provides a model in which local unions make use of 'work-to-rule' practices to negotiate a wage rate that exceeds the central wage floor. ${ }^{2}$ The link between the two tiers of the wage determination process is explicitly modelled: when bargaining at the industry-level, central unions fully anticipate that the negotiated wage will constitute the fall-back position of firm-level unions during subsequent local bargaining. As a result, the expected wage cushion is fully reflected in central negotiations. A competing view associates the wage cushion with efficiency wage policies pursued by the firms. Muysken and van Veen (1996) offer a model in which, rather than forced by local unions to divide an exogenous amount of rents, employers have a rational incentive to pay a mark-up on top of the contractual wage in order to maximise worker effort. Their paper provides, therefore, an alternative explanation for the wage cushion, which is expected to be particularly relevant in countries where centralised negotiations are not typically followed by local collective bargaining. ${ }^{3}$ A common feature of this line of work is the use of a representative firm framework. Therefore, the implication of firm heterogeneity for wage setting - which is the central focus of our paper - is never an issue in this literature.

A set of contributions in the union-oligopoly literature are also relevant in our context. The seminal paper by Dowrick (1989), and several extensions (e.g., Dhillon and Petrakis, 2002), offer oligopoly models with centralised union wage setting. ${ }^{4}$ There are, however, two crucial differences between this line of work and our paper. First, the assumption that firms are homogeneous. Second, the absence of local (firm-specific) wage setting following centralised bargaining. As a result, in all these models the actual paid wage is always equal to the central contracted wage.

We would also like to draw attention to a recent literature on how firm heterogeneity influences wage determination. Building on the influential paper of Melitz (2003), recent work by Egger and Kreickemeier (2008) and Davis and Harrigan (2007) shows that, in the presence of firm-specific

\footnotetext{
${ }^{2}$ Holden (1988), Hibbs and Locking (1996) and Ordine (1996) provide related contributions.

${ }^{3} \mathrm{~A}$ limiting feature of their model, however, is that the central wage floor is exogenous throughout the analysis.

${ }^{4}$ Bastos and Kreickemeier (2007) provide a related analysis in a general equilibrium context.
} 
efficiency wage policies, firm heterogeneity leads to different wages for ex-ante identical workers. ${ }^{5}$ Neither of these papers, however, focuses on union wage setting or two-tiered wage setting systems.

Finally, we would like to place our empirical work within the received literature. The empirical analysis by Cardoso and Portugal (2005) is clearly the closest to our own. Using the same dataset employed in this paper, they propose a new methodology to infer the contractual wage for each job category from actual paid wages. Specifically, they show that the mode of the distribution of the base wage for each job category within each collective agreement corresponds with remarkable accuracy to the wage set through collective bargaining. ${ }^{6}$ We will use the same procedure here to compute the union wage floor and the wage cushion. Cardoso and Portugal then report evidence that a significant proportion of workers covered by collective agreements actually receive wages well above the union wage floor. Although agreements are not ordinarily supplemented by local collective bargaining, firms unilaterally adjust wage policies to reflect their specific conditions. Using a cross-section of the matched worker-firm data for 1999, they find that the wage cushion stretches the returns to worker and firm attributes. Crucially, however, Cardoso and Portugal do not focus on how the degree of firm heterogeneity influences wage setting, which is the main contribution of this paper.

The remainder of the paper is organised as follows. In Section 2 we present a theoretical model and derive predictions for the empirical analysis. In Section 3 we discuss the empirical implementation. Our empirical findings are presented in Section 4. Finally, Section 5 offers some concluding remarks.

\section{$2 \quad$ A theoretical model}

Consider an industry consisting of two firms, each producing a differentiated product. Inverse demand for the two products is given by

$$
p_{i}=a-q_{i}-b q_{j}, \quad i, j=1,2, \quad i \neq j,
$$

where $q_{i}$ is quantity of product $i$, supplied by firm $i$, and $b \in(0,1)$ is an inverse measure of the degree of product differentiation. Where appropriate, we will later refer to $b$ as a measure of the intensity of competition in the industry.

Each firm uses labour as the only factor of production in a constant-returns-to-scale technology,

\footnotetext{
${ }^{5}$ The main focus of these papers is then on how trade liberalisation is likely to affect within-group wage inequality, and other labour market outcomes.

${ }^{6}$ To support this claim, they examine the relationship between the contractual wage for each worker category, obtained directly from published collective agreements, and the corresponding modal base wage in some pre-selected industries. Such comparisons confirm the high accuracy of this indicator, which is then applied in the remaining analysis.
} 
given by the following production functions:

$$
\begin{aligned}
& q_{1}=\phi(1+s) l_{1}, \\
& q_{2}=\phi(1-s) l_{2} .
\end{aligned}
$$

We introduce heterogeneity among firms, not workers. Workers are assumed to be ex ante identical, but technological (or managerial) differences among firms imply that firm heterogeneity is reflected in differences in labour productivity. The mean productivity in the industry is given by $\phi$, while the parameter $s \in(0,1)$ measures the productivity spread (or the degree of firm heterogeneity). ${ }^{7}$

We make the crucial assumption that the wage a firm has to pay its workers reflects firm-level rent-sharing. One way to obtain this feature is to adopt the 'fair wage' hypothesis. Assume, as in Akerlof and Yellen (1990), that workers condition their effort on the wage paid relative to the wage considered to be fair. If workers receive at least the 'fair wage', they provide a normal level of effort. By an appropriate choice of effort function, it will then be optimal for the firm to pay the fair wage. ${ }^{8}$ With this assumption, profits are given by

$$
\pi_{i}=p q_{i}-w_{i} l_{i}, \quad i=1,2
$$

where $w_{i}$ is the fair wage paid to workers at firm $i$.

It remains to establish the determinants of the fair wage. We use an internal reference perspective and assume that the fair wage depends on the firm's ability to pay. More specifically, we assume that the fair wage is given by a weighted average of the wage set by a central trade union and the firm's revenue per worker. ${ }^{9}$ The former constitutes a contracted wage floor for the industry, while the latter is the firm's maximum possible wage offer. Denoting the contracted wage floor by $\bar{w}$, the fair wage in firm $i$ is given by

$$
w_{i}=\beta \bar{w}+(1-\beta)\left(\frac{p_{i} q_{i}}{l_{i}}\right)
$$

\footnotetext{
${ }^{7}$ It is worth pointing out that the duopoly assumption is made for expositional simplicity and is not crucial for the generality of the results. It can easily be verified that our main results are qualitatively unaffected by adding more firms to the industry while maintaining a symmetric firm heterogeneity.

${ }^{8}$ For example, as in Akelof and Yellen (1990), if worker effort is given by$$
e=\min \left(\frac{w}{w^{*}}, 1\right)
$$

where $w$ is the actual paid wage and $w^{*}$ is the fair wage, the firm will not benefit from paying less than the fair wage, since effort decreases proportionally if the wage falls short of what the workers consider to be fair.

${ }^{9}$ This definition of a fair wage is similar in spirit to the one used by Danthine and Kurmann (2006). A somewhat different internal reference perspective is used by Akerlof and Yellen (1990), who assume that workers of different skills compare their wages to other co-workers within the same firm.
} 
where $\beta \in(0,1)$ is the weight attached to the wage floor relative to the maximum possible wage offer. When the fair wage is, to some degree, determined by internal factors, intra-industry differences in labour productivity will be reflected in wage differences across firms. Notice also that there is an obvious analytical advantage of this particular specification, namely that a similar wage outcome can result from local wage bargaining. ${ }^{10}$ Thus, we can alternatively interpret $\beta$ as the relative bargaining power of the firm in local bargaining.

The industry wage floor, $\bar{w}$, is set by a central monopoly trade union representing all workers in the industry. Assuming rent-maximising behaviour, the union's objective function is given by

$$
U=\sum_{i=1}^{2}\left(w_{i}-r\right) l_{i}
$$

where $r$ is the reservation wage level. Standard assumptions on the determinants of $r$ would be the minimum wage level, the level of unemployment benefits, or simply the disutility of work. ${ }^{11}$

Assuming Cournot competition between the firms in the industry, we consider the following sequence of events:

1. The central trade union sets the wage floor $\bar{w}$ that applies for the industry.

2. The firms simultaneously and independently choose employment levels, taking into account the wage rates they need to pay in order to induce normal effort from their workers.

3. Production takes place and payoffs are realised.

\subsection{Solving for the Cournot-Nash equilibrium}

For a given wage floor, $\bar{w}$, the two firms decide how many workers to hire, taking into account that they have to pay them the fair wage, given by (5), to induce normal worker effort. This yields the following labour demand functions ${ }^{12}$

$$
l_{1}(\bar{w})=\frac{a \phi(1-s)(1+s)-\bar{w}(1-3 s)}{3 b \phi^{2}(1-s)(1+s)^{2}}
$$

\footnotetext{
${ }^{10} \mathrm{It}$ is straightforward to show that the wage given in (5) corresponds exactly to the wage resulting from efficient bargaining between the firm and a rent-maximising local union, where the disagreement payoffs of both parties are zero.

${ }^{11}$ With heterogeneous firms, there would be an incentive for a central union to wage discriminate, by setting firm-specific wage floors. Wage discrimination by a central trade union is, however, rarely observed in practice, a fact that can be explained by bargaining costs and/or egalitarian norms.

${ }^{12} \mathrm{We}$ assume that labour demand is always positive for both firms, ruling out the possibility that the least productive firm might not survive in the market. This essentially requires that the productivity spread, $s$, is sufficiently low.
} 


$$
l_{2}(\bar{w})=\frac{a \phi(1-s)(1+s)-\bar{w}(1+3 s)}{3 b \phi^{2}(1-s)^{2}(1+s)} .
$$

The corresponding fair wages are then found by inserting the equilibrium expressions for $l_{1}(\bar{w})$ and $l_{2}(\bar{w})$ into $(5)$, yielding

$$
w_{1}(\bar{w})=\frac{a \phi(1-s)(1+s)(2-b)(1-\beta)+\bar{w}(2-b)(1+b+\beta)-\bar{w} s(2+b)(1-b+\beta)}{(1-s)(2+b)(2-b)}
$$

and

$$
w_{2}(\bar{w})=\frac{a \phi(1-s)(1+s)(2-b)(1-\beta)+\bar{w}(2-b)(1+b+\beta)+\bar{w} s(2+b)(1-b+\beta)}{(1+s)(2+b)(2-b)} .
$$

It is straightforward to verify that wages paid at both firms are increasing in the wage floor, and that the wage difference $\left(w_{1}-w_{2}\right)$ is increasing in the degree of firm heterogeneity, as measured by $s$.

At the outset of the game, the wage floor is set by a central rent-maximising trade union. Thus, $\bar{w}$ is given by

$$
\bar{w}=\arg \max \left\{U=\left(w_{1}(\bar{w})-r\right) l_{1}(\bar{w})+\left(w_{2}(\bar{w})-r\right) l_{2}(\bar{w})\right\}
$$

yielding

$$
\bar{w}=\frac{(2-b)\left[a \phi(1-s)(1+s)(2-b)(b+2 \beta)+r(2+b)\left(2-b+(2+b) s^{2}\right)\right]}{2\left[(2-b)^{2}(1+b+\beta)+s^{2}(2+b)^{2}(1-b+\beta)\right]} .
$$

From (9)-(10) and (11) it is immediately evident that both the wage floor and the actually paid wages are increasing in the level of labour productivity $(\phi)$, as expected. For the subsequent analysis of the wage effects of firm heterogeneity, it is useful to define some wage concepts. The wage cushion in firm $i$ is given by $\eta_{i}=w_{i}-\bar{w}$, the average wage cushion is given by $\mu=\frac{\Sigma_{i=1}^{2}\left(\eta_{i} l_{i}\right)}{\Sigma_{i=1}^{2} l_{i}}$, while the average (actual paid) wage is given by $\omega=\bar{w}+\mu$.

\subsection{Firm heterogeneity and wages}

In this section we use our model to analyse the main question posed in the paper; how the distribution of firm productivities in a given unionised industry affect wage setting, at industry and firm level. 


\subsubsection{The wage floor}

The effect of firm heterogeneity on the industry wage floor is derived from (11):

$$
\frac{\partial \bar{w}}{\partial s}=-2 s(2-b)^{2} \frac{a \phi\left[4(1+\beta)-b^{2}(3-\beta)\right](b+2 \beta)-(1-\beta) b r(2+b)^{2}}{\left[(2-b)^{2}(1+b+\beta)+s^{2}(2+b)^{2}(1-b+\beta)\right]^{2}} .
$$

The sign of this expression is determined by the sign of the numerator. Since this is clearly positive, implying $\partial \bar{w} / \partial s<0$, if $r \rightarrow 0, b \rightarrow 0$ or $\beta \rightarrow 1$, we establish the most general result of this section:

Proposition 1 A higher degree of firm heterogeneity in the industry will reduce the wage floor if one or more of the following conditions are met:

(i) The reservation wage level, $r$, is sufficiently low.

(ii) The degree of competition in the industry, $b$, is sufficiently low.

(iii) The firms' share of rents, $\beta$, is sufficiently high.

The intuition for this result is not straightforward. The central union's wage setting incentives can be decomposed into two different channels: the effect of the wage floor on (i) aggregate employment and (ii) actual wages. Increased firm heterogeneity will change the union's wage setting incentives through both channels, and in opposite directions.

(i) Increased firm heterogeneity implies that aggregate employment becomes more elastic with respect to the wage floor. This elasticity is given by

$$
\varepsilon(\bar{w})=-\frac{\partial\left(\sum_{i=1}^{2} l_{i}(\bar{w})\right)}{\partial \bar{w}} \frac{\bar{w}}{\sum_{i=1}^{2} l_{i}(\bar{w})}=\frac{\left(2-b+s^{2}(2+b)\right) \bar{w}}{\phi a(1-s)(1+s)(2-b)-\left(2-b+(2+b) s^{2}\right) \bar{w}},
$$

from which we derive

$$
\frac{\partial \varepsilon(\bar{w})}{\partial s}=\frac{8 a s \bar{w} \phi(2-b)}{\left[\phi a(1-s)(1+s)(2-b)-\left(2-b+(2+b) s^{2}\right) \bar{w}\right]^{2}}>0 .
$$

A decomposition of the elasticity shows that more heterogeneity increases (reduces) labour demand elasticity for the low (high) productivity firm. This is because higher (lower) labour productivity reduces (increases) the effect of an increase in the effective wage rate (i.e., the price of one efficiency unit of labour) on labour demand. Notice, however, that the impact of a (marginal) change in labour productivity on the relationship between the wage rate and the effective wage rate, is smaller the higher the labour productivity is. Therefore, the effect on labour demand elasticity in the low-productivity firm is always dominating. Thus, all else equal, a central union in a more heterogeneous industry will set a lower wage floor to stimulate employment in the low-productivity firm. 
(ii) Increased firm heterogeneity also affects how an increase in the wage floor translates into an increase in actual paid wages. Specifically, the positive relationship between the wage floor and actual wages becomes overall stronger. From (9) and (10) we can see that it becomes stronger for the high-productivity firm and weaker for the low-productivity firm,

$$
\begin{aligned}
\frac{\partial^{2} w_{1}}{\partial s \partial \bar{w}} & =\frac{2 b(1-\beta)}{(2-b)(2+b)(1-s)^{2}}>0, \\
\frac{\partial^{2} w_{2}}{\partial s \partial \bar{w}} & =-\frac{2 b(1-\beta)}{(2-b)(2+b)(s+1)^{2}}<0,
\end{aligned}
$$

but overall stronger, since $\left|\frac{\partial^{2} w_{1}}{\partial s \partial \bar{w}}\right|>\left|\frac{\partial^{2} w_{2}}{\partial s \partial \bar{w}}\right|$. Thus, all else equal, a central union in a more heterogeneous industry will set a higher wage floor to induce higher actual wages in the most productive firm.

The relative strengths of these two opposite incentives are determined by the parameter configuration. A lower reservation wage level means that, all else equal, employment effects are relatively more important, strengthening the first incentive relative to the second. On the other hand, a lower degree of competition and a lower degree of local rent-sharing imply that the relationship between the wage floor and actual wages are less influenced by firm heterogeneity, making the second incentive less important. Why? Because less competition in the market means that productivity differences are to a lesser extent reflected in relative market shares. Consequently, more heterogeneity has a lower impact on the allocation of rents, which partly determine the actual paid wages, when there is less competition in the industry. Similarly, if the firms share less rents with their workers, productivity differences translate, to a lower degree, into differences in actual wages. Thus, less competition and/or less local rent-sharing imply that the degree of firm heterogeneity has a lower impact on the relationship between the wage floor and actual paid wages. Indeed, from (15) and (16) we see that the relationship between $\bar{w}$ and $w_{i}$ is independent of $s$, if $b \rightarrow 0$ or $\beta \rightarrow 1$.

It should be emphasised that the parameter configuration that yields a positive relationship between firm heterogeneity and the industry wage floor is quite limited. To provide an illustration of this, consider the case of maximum competition, $b=1$. In this case, it is possible to show that $\partial \bar{w} / \partial s<0$, for all admissible values of $r$, if $\beta>\frac{2-3 s(1+s)}{5+3 s(2-s)}(<0.4)$. Thus, for 'reasonable' parameter configurations, the dominant incentive of the central union is to stimulate employment in low-productivity firms, resulting in a lower wage floor in more heterogeneous industries.

\subsubsection{The wage cushion}

For the sake of analytical feasibility, we will explore the effects of firm heterogeneity on the wage cushion, and thus on actual wages, by considering the special case of homogeneous products and 
a zero reservation wage. ${ }^{13}$ This restricts the parameter configurations to a subset where there is always a negative relationship between the degree of firm heterogeneity and the wage floor, which, as argued above, we consider to be the most likely case. Setting $b=1$ and $r=0$, the equilibrium wage expressions are given by

$$
\begin{aligned}
& \bar{w}=\frac{a \phi(2 \beta+1)(1-s)(1+s)}{2\left(2+\beta+9 \beta s^{2}\right)} \\
& \eta_{1}=\frac{a \phi(1+s)(1-\beta)[1+s+2 s \beta(1+3 s)]}{2\left(2+\beta+9 \beta s^{2}\right)} \\
& \eta_{2}=\frac{a \phi(1-s)(1-\beta)[1-s-2 s \beta(1-3 s)]}{2\left(2+\beta+9 \beta s^{2}\right)}, \\
& \omega=\frac{a \phi(1-s)(1+s)\left[1+4 s^{2} \beta(1-\beta)\right]}{2\left(1+s^{2}(4 \beta-1)\right)} .
\end{aligned}
$$

It is easily shown that increased firm heterogeneity will increase (decrease) the wage cushion in the high (low) productivity firm; $\partial \eta_{1} / \partial s>0$ and $\partial \eta_{2} / \partial s<0$, as expected. More interesting is the effect on the average wage cushion, given by $\mu=\omega-\bar{w}$. Using (17) and (20), this effect is

$$
\frac{\partial \mu}{\partial s}=\frac{2 a s \phi(1-\beta)\left[(1-s)^{2}(1+s)^{2}+\Psi\right]}{\left(4 s^{2} \beta-s^{2}+1\right)^{2}\left(\beta+9 s^{2} \beta+2\right)^{2}},
$$

where $\Psi=-648 s^{8} \beta^{4}+162 s^{8} \beta^{3}-144 s^{6} \beta^{4}-576 s^{6} \beta^{3}+72 s^{6} \beta^{2}-8 s^{4} \beta^{4}-100 s^{4} \beta^{3}-198 s^{4} \beta^{2}+$ $8 s^{4} \beta+32 s^{2} \beta^{3}+12 s^{2} \beta^{2}-24 s^{2} \beta+2 \beta^{3}+10 \beta^{2}+8 \beta$.

The sign of (21) is given by the sign of the numerator, where the sign of $\Psi$ is a priori ambiguous. By numerical simulations, it can be shown that $\partial \mu / \partial s>0$, for all $\beta$, if $s<\bar{s} \approx 0.48$. Since $s$ measures the percentage difference from the mean, $s<\bar{s}$ appears to be a weak condition. Thus, we conclude that, for 'reasonable' parameter configurations, a higher degree of firm heterogeneity leads to a lower industry wage floor but a higher average wage cushion. An increase in the productivity spread implies a more uneven distribution of rents. For a given wage floor, this should lead to a lower (higher) wage cushion in low (high) productivity firms. However, since the central union responds by lowering the industry wage floor, there is less need for a reduction in the wage cushion in low-productivity firms, while there is more room for an increase in the wage cushion in highproductivity firms. Furthermore, a higher productivity spread also implies a reallocation of workers towards the high-productivity firms. Both these effects contribute to an increase in the average wage cushion.

\footnotetext{
${ }^{13}$ Notice that assuming a zero reservation wage is equivalent to letting the central trade union maximise the total wage bill.
} 
The effect of firm heterogeneity on the average (actual paid) wage, $\omega$, is given by

$$
\frac{\partial \omega}{\partial s}=\frac{\partial \bar{w}}{\partial s}+\frac{\partial \mu}{\partial s}
$$

which, due to the potentially opposite signs of $\partial \bar{w} / \partial s$ and $\partial \mu / \partial s$, is generally ambiguous. From (22), the total effect is given by

$$
\frac{\partial \omega}{\partial s}=-\frac{4 a s \beta \phi\left[\beta+s^{2}(1-\beta)\left(4 s^{2} \beta+2-s^{2}\right)\right]}{\left(4 s^{2} \beta-s^{2}+1\right)^{2}}<0
$$

implying that the effect via the industry wage floor always dominates, establishing a negative relationship between firm heterogeneity and average actual paid wages.

Based on the above analysis, we postulate the following hypotheses for the empirical analysis. Industries exhibiting larger firm heterogeneity, measured by a mean-preserving spread of labour productivites, are expected to be characterised by

(i) a lower industry wage floor;

(ii) a higher (average) wage cushion;

(iii) a lower (average) actual paid wage.

\section{Empirical implementation}

\subsection{Data}

We test our theory using data from Quadros de Pessoal (QP) for the years 1991 to 2000. This is an administrative dataset that comprises information on virtually all workers, firms and collective agreements from the private sector in Portugal. It gathers information from a compulsory census run by the Ministry of Employment, covering the population of firms with wage earners in manufacturing and services. Each firm is required to provide information on an annual basis about its characteristics and those of each individual that comprises its workforce.

Firm-level information includes annual sales, number of employees, industry code, geographical location and date of constitution. The set of worker characteristics includes wages (monthly base wage and other components of pay), gender, schooling, date of starting, occupation and hours worked. In addition, the worker data includes unique identifiers for the collective bargaining agreement that covers the worker, as well as for the corresponding professional category for collective bargaining purposes. The first digit of the collective agreement identifier indicates the type of 
contract that covers the worker (sectoral, multi-firm, firm, mandatory regime). A worker may also be matched to the firm.

An important feature of these data is that particular care is placed on the reliability of the information. Indeed, the data are used by the Ministry of Employment for checking the employer's compliance with labour law. Moreover, Portuguese law makes it compulsory for firms to make this information available to every worker in a public place of the establishment.

Extensive checks have been performed to guarantee the accuracy of worker and firm data, according to the procedures outlined in the Appendix. After these checks, we kept for analysis full-time wage earners working at least 25 hours a week, aged between 16 and 65, earning at least the national minimum wage, employed in firms located in mainland Portugal. As in Cardoso and Portugal (2005), because the contractual wage is computed as the mode of the distribution of base wages for each job category within each collective agreement, only categories comprising at least 50 workers and agreements with at least 1,000 workers were kept for the analysis. In line with the theoretical framework of the previous section, we restrict the analysis to workers covered by sectoral agreements, who represent about $88 \%$ of these workers. The resulting panel comprises information on 1,886,703 workers, 216,681 firms and 198 sectoral agreements, yielding a total of 7,420,900 worker-year observations.

\subsection{Computing the wage floor and the wage cushion}

Following Cardoso and Portugal (2005), we distinguish between contractual wages, wage cushion and actual wages. By comparing the wage information available in Quadros de Pessoal with information on contractual wages for each worker category published in collective agreements, Cardoso and Portugal show that the mode of the base wage distribution for each professional category within each collective agreement corresponds strongly, in some cases with remarkable accuracy, to the wage that is set via collective bargaining. ${ }^{14}$ We adopt the same procedure here to compute the contractual wage. The wage cushion for worker $k=\{1, \ldots, N\}$ in year $t=\{1, \ldots, T\}$ is defined as:

$$
\eta_{k t}=\ln \left(\frac{w_{k t}}{\bar{w}_{c a t}}\right)
$$

where $w_{k t}$ is the overall monthly earnings actually received by individual $k$ in year $t$ (including the base wage, tenure-related and other regularly paid components) and $\bar{w}_{c a t}$ is the modal base wage

\footnotetext{
${ }^{14}$ Cardoso and Portugal explicitly check the relationship between the contractual wages and the mode of the base wage distribution for each worker category, within each collective agreement, for three different (and large) industries in two different years. They find that the correlation between the contractual wage and the mode of the base wage ranges from 77 to 99 percent.
} 
for the worker's professional category, within the collective agreement that covers the worker in year $t$. The following subsection outlines the empirical strategy for examining the effect of the levels and distribution of firm productivities in each industry on contractual wages, the wage cushion and actual wages.

\subsection{Econometric model}

We adopt the following econometric specification:

$$
\text { wage }_{k t}=\mathbf{x}_{i t} \boldsymbol{\gamma}+\mathbf{y}_{j t} \boldsymbol{\delta}+\alpha \phi_{a t}+\beta s_{a t}+v_{k}+\lambda_{v}+\tau_{r}+\theta_{t}+\mu_{k t}
$$

As the dependent variable, we consider the central wage floor, the wage cushion and actual wage, as defined in the previous sub-section: wage $_{k t}=\left\{\bar{w}_{c a t}, \eta_{k t}, w_{k t}\right\}$. Our central variables $\phi_{a t}$ and $s_{a t}$ measure, respectively, the mean and the spread of firm labour productivity within the collective agreement that covers the worker. Our main interest lies in the coefficient $\beta$, which captures the effect of firm heterogeneity. The mean of firm labour productivity, $\phi_{a t}$, is included since, in order meaningfully to compare firm heterogeneity across collective agreements, we obviously need to control for the mean. The set of explanatory variables also includes: $\mathbf{x}_{k t}$, a vector of individual characteristics; $\mathbf{y}_{j t}$, a vector of characteristics for firm $j$ at which worker $k$ is employed in year $t$; $v_{k}$, a pure individual unobserved effect; $\lambda_{v}$, a pure industry effect; $\tau_{r}$, a pure region effect; $\theta_{t}$, a fixed time effect; and, finally, $\mu_{k t}$ is an exogenous disturbance.

In the empirical analysis, we measure $\phi_{a t}$ and $s_{a t}$, respectively, as the average and the mean absolute deviation (MAD) of firm sales per employee within the collective agreement that covers the worker. ${ }^{15,16}$ The vector of worker control variables includes gender, age, age squared, years of schooling, tenure, tenure less than one year and four occupational dummies based on the 1988 International Standard Classification of Occupations (ISCO-88). This classification provides four skill-levels which are based on (i) the level of general education required to perform a job; and (ii) the job-related formal training required to perform a job (ILO, 1990). ${ }^{17}$ The vector of firm characteristics includes firm size (log of number of employees), age, and nominal average labour productivity (log of firm annual sales per employee). To control for unobserved industry characteristics, all regressions include a full set of fifteen industry-dummies. In addition, the regressions include five regional dummies to account for disparities in earnings across regions. As is standard in the literature, wages and firm sales are deflated by the CPI and the GDP deflator, respectively. ${ }^{18}$

\footnotetext{
${ }^{15}$ In the absence of data on intermediate inputs and inventories, the use of sales per employee to proxy firm labour productivity is standard in the literature (see, for example, Franco and Philippon, 2007).

${ }^{16}$ As a robustness check, we also use the standard deviation as an alternative spread measure. See Section 4.2.

${ }^{17}$ See the Appendix for a detailed description.

${ }^{18}$ Data on CPI and GDP deflators come from the National Statistics Institute of Portugal.
} 
Table 1: Descriptive statistics, Regressions data, 1991-2000

\begin{tabular}{lrrrr}
\hline \hline & Mean & SD & Min & Max \\
\hline Wage floor (log of wage floor in Euros) & 6.06 & 0.33 & 5.37 & 8.79 \\
Actual wage (log of actual wage in Euros) & 6.29 & 0.45 & 5.71 & 10.30 \\
Wage cushion= $\ln \left(\frac{\text { actual wage }}{\text { wage floor }}\right)$ & 0.23 & 0.35 & -2.77 & 4.57 \\
Wage cushion $=\ln \left(\frac{\text { base wage }}{\text { wage floor }}\right)$ & 0.11 & 0.32 & -2.82 & 4.57 \\
Male & 0.61 & 0.49 & 0 & 1 \\
Schooling & 6.23 & 3.29 & 0 & 16 \\
Age & 36.01 & 11.03 & 16 & 65 \\
Age squared & $1,418.50$ & 861.01 & 256 & 4,225 \\
Tenure & 8.01 & 8.41 & 0 & 54 \\
Tenure less than 1 year & 0.11 & 0.31 & 0 & 1 \\
Skill & 1.97 & 0.61 & 1 & 4 \\
Firm size (log) & 4.26 & 1.89 & 0 & 9.56 \\
Firm age & 21.55 & 19.50 & 0 & 305 \\
Firm labour productivity (log) & 3.72 & 1.25 & -15.16 & 14.25 \\
Average productivity & 75.94 & 73.15 & 0.03 & $1,368.40$ \\
Productivity spread (10 ${ }^{3}$ Euros) & 72.54 & 103.82 & 0 & $2,482.06$ \\
$\quad$ Mean absolute deviation (MAD) & 538.61 & $1,692.02$ & 0 & $14,706.36$ \\
$\quad$ Standard deviation (SD) & \multicolumn{5}{c}{$1,484,243$} \\
\hline$\quad$ Observations &
\end{tabular}

\section{Summary statistics and econometric results}

Due to computational constraints, in the regression analysis we use a 20 percent random sample of workers from the checked panel (keeping all yearly information for the sampled workers). Table 1 presents descriptive statistics on these data. The average wage cushion is 0.23 , confirming the importance of firm-specific arrangements following industry-level collective bargaining for wage formation. ${ }^{19}$ Furthermore, the summary statistics reveal that our measures of the productivity spread exhibit significant dispersion. ${ }^{20}$ Such variation will be particularly useful for identifying the effect of firm heterogeneity on wages in the econometric analysis.

\subsection{Baseline model}

In order to control for worker-specific unobserved heterogeneity, we exploit the longitudinal nature of the data and estimate individual fixed-effects models. In addition, the regressions include a

\footnotetext{
${ }^{19}$ The wage cushion is negative whenever the observed mode of base wage is an inaccurate measure of the bargained wage or when workers do not work the full month (either because they are sick or hired during the month). This happens for $16.67 \%$ of our sample.

${ }^{20}$ The productivity spread measures are null when a single wage agreement covers a single firm, which corresponds to 25 observations in our sample.
} 
full set of industry, region, and year dummies. For each estimate, we provide in parentheses the standard errors that account for clustering by collective wage agreement and year. Table 2 presents the fixed effects results for our baseline specification (25).

Table 2: Heterogeneity and wages, fixed effects

\begin{tabular}{|c|c|c|c|}
\hline Variable & Wage floor & Wage cushion & Actual wage \\
\hline Schooling & $\begin{array}{l}.002^{* * *} \\
(.0003)\end{array}$ & $\begin{array}{l}.004^{* * *} \\
(.0005)\end{array}$ & $\begin{array}{l}.007^{* * *} \\
(.0005)\end{array}$ \\
\hline Age & $\begin{array}{l}.014^{* * *} \\
(.001)\end{array}$ & $\begin{array}{c}.009^{* * *} \\
(.001)\end{array}$ & $\begin{array}{c}.023^{* * *} \\
(.001)\end{array}$ \\
\hline Age2 & $\begin{array}{c}-.0002^{* * *} \\
(.00001)\end{array}$ & $\begin{array}{c}-.0001^{* * *} \\
(.00001)\end{array}$ & $\begin{array}{c}-.0003^{* * *} \\
(.00002)\end{array}$ \\
\hline Tenure & $\begin{array}{l}.003^{* * *} \\
.0002)\end{array}$ & $\begin{array}{c}-.0007^{* * *} \\
(.0002)\end{array}$ & $\begin{array}{l}.002^{* * *} \\
(.0002)\end{array}$ \\
\hline Tenure less 1 year & $\begin{array}{c}-.0008 \\
(.001)\end{array}$ & $\begin{array}{c}-.014^{* * *} \\
(.002)\end{array}$ & $\begin{array}{c}-.015^{* * *} \\
(.002)\end{array}$ \\
\hline Skill 2 & $\begin{array}{c}.096^{* * *} \\
(.005)\end{array}$ & $\begin{array}{c}-.050^{* * *} \\
(.004)\end{array}$ & $\begin{array}{c}.046^{* * *} \\
(.003)\end{array}$ \\
\hline Skill 3 & $\begin{array}{c}.229^{* * *} \\
(.008)\end{array}$ & $\begin{array}{c}-.119^{* * *} \\
(.007)\end{array}$ & $\begin{array}{c}.110^{* * *} \\
(.004)\end{array}$ \\
\hline Skill 4 & $\begin{array}{c}.219^{* * *} \\
(.013)\end{array}$ & $\begin{array}{c}-.052^{* * *} \\
(.013)\end{array}$ & $\begin{array}{c}.167^{* * *} \\
(.006)\end{array}$ \\
\hline Firm size $(\log )$ & $\begin{array}{l}.015^{* * *} \\
(.0008)\end{array}$ & $\begin{array}{l}.020^{* * *} \\
(.0009)\end{array}$ & $\begin{array}{c}.035^{* * *} \\
(.001)\end{array}$ \\
\hline Firm age & $\begin{array}{c}-.0002^{* * *} \\
(.00006)\end{array}$ & $\begin{array}{c}-.0002^{* *} \\
(.0001)\end{array}$ & $\begin{array}{c}-.0005^{* * *} \\
(.00008)\end{array}$ \\
\hline Firm labour productivity (log) & $\begin{array}{l}.001^{* *} \\
(.0005)\end{array}$ & $\begin{array}{l}.005^{* * *} \\
(.0007)\end{array}$ & $\begin{array}{l}.006^{* * *} \\
(.0007)\end{array}$ \\
\hline Average productivity & $\begin{array}{c}.0009^{* * *} \\
(.0001)\end{array}$ & $\begin{array}{c}-.0006^{* * *} \\
(.0001)\end{array}$ & $\begin{array}{c}.0003^{* * *} \\
(.00008)\end{array}$ \\
\hline Productivity spread (MAD) & $\begin{array}{c}-.0005^{* * *} \\
(.00007)\end{array}$ & $\begin{array}{c}.0003^{* * *} \\
(.00007)\end{array}$ & $\begin{array}{c}-.0002^{* * *} \\
(.00004)\end{array}$ \\
\hline Implied wage-spread elasticity & {$[-.037]$} & {$[.023]$} & {$[-.014]$} \\
\hline Observations & $1,484,243$ & $1,484,243$ & $1,484,243$ \\
\hline$R^{2}$ within & .076 & .029 & .085 \\
\hline$F$ statistic & 117.18 & 74.87 & 170.84 \\
\hline $\mathrm{P}$-value & .000 & .000 & .000 \\
\hline
\end{tabular}


The results shown here clearly confirm the predictions from our theoretical model. Even after including a large set of worker and firm controls, a larger firm heterogeneity, expressed by the mean absolute deviation (MAD), implies a significantly (at the 1 per cent level) lower industry wage floor and higher wage cushion. The actual wage declines as well, as the effect on the wage floor dominates the effect on the wage cushion. Moreover, in all three cases, the magnitude of the impacts, measured by the implied wage-spread elasticities, is noticeable. For instance, if firm heterogeneity in the industry doubles, the elasticity figures indicate that, on average, the wage floor declines by $3.7 \%$, the wage cushion rises by $2.3 \%$ and the actual wage paid reduces by $1.4 \%$. These impacts are certainly non-negligible, taking into account that the distribution of the MAD across sectoral agreements and time is very wide. For example, half of the mean MAD is at the 41st percentile, while the double of the mean MAD is at the 92 nd percentile.

The effect of firm labour productivity has the expected positive sign for all wage measures. Notice also that the effect on the wage cushion is pronouncedly stronger than on the wage floor, suggesting the presence of firm-level rent-sharing, which is a key mechanism in our theoretical model. The impact of the average productivity level qualitatively follows that of firm-level productivity, except for the case of the wage cushion, where there is a negative relationship. This probably reflects a certain degree of asymmetry in the productivity distribution.

The remaining estimates shown in the table are all significant and present the expected sign. They also provide further confirmation to Cardoso and Portugal's (2005) finding (based on a single cross-section) that the wage cushion tends to stretch the impact of worker and firm attributes on wages.

One potential concern with the fixed effects estimates is that both the contractual wage and the actual paid wage are left-censored. The former cannot fall below the national minimum wage, while the latter cannot be lower than the union wage floor, implying that the wage cushion cannot be negative. ${ }^{21}$ As a result, our least squares estimates might be biased. We directly address this concern by estimating Tobit random effects models.

An inspection of Table 3 shows that controlling for censoring effects only reinforce our previous findings. The marginal effects of the spread of firm labour productivity are (again) significant at the 1 per cent level and slightly larger than the ones found earlier. The elasticity effects are therefore larger. The exception is the elasticity for the wage cushion. According to the Tobit estimates, if firm heterogeneity doubles, then the wage floor reduces by $5.7 \%$ while the actual wage paid reduces by $2.7 \%$.

\footnotetext{
${ }^{21}$ Censoring affects $2 \%$ and $16.7 \%$ of the observations in each case, respectively.
} 
Table 3: Heterogeneity and wages, Tobit random effects

\begin{tabular}{|c|c|c|c|}
\hline Variable & Wage floor & Wage cushion & Actual wage \\
\hline Male & $\begin{array}{c}.092^{* * *} \\
(.0008)\end{array}$ & $\begin{array}{c}.117^{* * *} \\
(.001)\end{array}$ & $\begin{array}{c}.203^{* * *} \\
(.001)\end{array}$ \\
\hline Schooling & $\begin{array}{c}.018^{* * *} \\
(.0001)\end{array}$ & $\begin{array}{c}.021^{* * *} \\
(.0002)\end{array}$ & $\begin{array}{l}.039^{* * *} \\
(.0002)\end{array}$ \\
\hline Age & $\begin{array}{c}.019^{* * *} \\
(.0002)\end{array}$ & $\begin{array}{c}.012^{* * *} \\
(.0002)\end{array}$ & $\begin{array}{l}.029^{* * *} \\
(.0002)\end{array}$ \\
\hline Age2 & $\begin{array}{c}-.0002^{* * *} \\
(2.06 \mathrm{e}-06)\end{array}$ & $\begin{array}{c}-.0001^{* * *} \\
(2.88 \mathrm{e}-06)\end{array}$ & $\begin{array}{c}-.0003^{* * *} \\
(2.78 \mathrm{e}-06)\end{array}$ \\
\hline Tenure & $\begin{array}{l}.004^{* * *} \\
(.00005)\end{array}$ & $\begin{array}{l}.002^{* * *} \\
(.00006)\end{array}$ & $\begin{array}{l}.005^{* * *} \\
(.00006)\end{array}$ \\
\hline Tenure less than 1 year & $\begin{array}{c}-.005^{* * *} \\
(.0006)\end{array}$ & $\begin{array}{c}-.016^{* * *} \\
(.0009)\end{array}$ & $\begin{array}{c}-.020^{* * *} \\
(.0008)\end{array}$ \\
\hline Skill 2 & $\begin{array}{c}.139^{* * *} \\
(.0007)\end{array}$ & $\begin{array}{c}-.028^{* * *} \\
(.0009)\end{array}$ & $\begin{array}{c}.070^{* * *} \\
(.0009)\end{array}$ \\
\hline Skill 3 & $\begin{array}{c}.325^{* * *} \\
(.001)\end{array}$ & $\begin{array}{c}-.010^{* * *} \\
(.002)\end{array}$ & $\begin{array}{c}.260^{* * *} \\
(.002)\end{array}$ \\
\hline Skill 4 & $\begin{array}{c}.346^{* * *} \\
(.002)\end{array}$ & $\begin{array}{c}.221^{* * *} \\
(.002)\end{array}$ & $\begin{array}{c}.470^{* * *} \\
(.002)\end{array}$ \\
\hline Firm size $(\log )$ & $\begin{array}{c}.025^{* * *} \\
(.0002)\end{array}$ & $\begin{array}{c}.028^{* * *} \\
(.0002)\end{array}$ & $\begin{array}{c}.048^{* * *} \\
(.0002)\end{array}$ \\
\hline Firm age & $\begin{array}{c}-.0003^{* * *} \\
(.00002)\end{array}$ & $\begin{array}{c}-.0002^{* * *} \\
(.00002)\end{array}$ & $\begin{array}{c}-.0005^{* * *} \\
(.00002)\end{array}$ \\
\hline Firm labour productivity (log) & $\begin{array}{c}.004^{* * *} \\
(.0002)\end{array}$ & $\begin{array}{c}.016^{* * *} \\
(.0003)\end{array}$ & $\begin{array}{c}.017^{* * *} \\
(.0002)\end{array}$ \\
\hline Average productivity & $\begin{array}{l}.001^{* * *} \\
(.00001)\end{array}$ & $\begin{array}{c}-.0005^{* * *} \\
(.00002)\end{array}$ & $\begin{array}{c}.0007^{* * *} \\
(.00002)\end{array}$ \\
\hline Productivity spread (MAD) & $\begin{array}{c}-.0008^{* * *} \\
(7.26 \mathrm{e}-06)\end{array}$ & $\begin{array}{c}.0003^{* * *} \\
(.00001)\end{array}$ & $\begin{array}{c}-.0004^{* * *} \\
(9.49 \mathrm{e}-06)\end{array}$ \\
\hline Implied wage-spread elasticity & {$[-.057]$} & {$[.021]$} & {$[-.027]$} \\
\hline Observations & $1,484,243$ & $1,484,243$ & $1,484,243$ \\
\hline Log likelihood & 35,782 & $-496,148$ & $-319,937$ \\
\hline$\chi^{2}$ statistic & 530,255 & 134,393 & 516,292 \\
\hline P-value & .000 & .000 & .000 \\
\hline Sigma-u & .182 & .236 & .266 \\
\hline
\end{tabular}

Notes: Significance levels: $\quad *: 10 \% \quad * *: 5 \% \quad * * *: 1 \%$. The regressions are estimated by the tobit random model and include industry, region and time effects.

The remaining estimates, once more, are significant at the 1 per cent level and follow previous literature. 


\subsection{Alternative measures of $\phi_{a t}$ and $s_{a t}$}

As an alternative to the MAD, we use the standard deviation (SD) of firm sales per worker within each collective agreement as a measure of the productivity spread. The upper (lower) part of Table 4 reports some selected results from the fixed effects (Tobit random effects) model. ${ }^{22}$

Table 4: Heterogeneity and wages, alternative measures

\begin{tabular}{|c|c|c|c|}
\hline Variable & Wage floor & "Wage cushion & Actual wage \\
\hline \multicolumn{4}{|l|}{ FIXED EFFECTS } \\
\hline Firm labour productivity (log) & $\begin{array}{l}.002^{* * *} \\
(.0005)\end{array}$ & $\begin{array}{l}.005^{* * *} \\
(.0007)\end{array}$ & $\begin{array}{l}.007^{* * *} \\
(.0007)\end{array}$ \\
\hline Average productivity & $\begin{array}{c}.0002^{* * *} \\
(.00005)\end{array}$ & $\begin{array}{c}-.0001^{* * *} \\
(.00004)\end{array}$ & $\begin{array}{c}.00008^{* *} \\
(.00003)\end{array}$ \\
\hline Productivity spread (SD) & $\begin{array}{c}-3.47 \mathrm{e}-07^{* * *} \\
(1.27 \mathrm{e}-06)\end{array}$ & $\begin{array}{l}1.61 \mathrm{e}-06 \\
(1.12 \mathrm{e}-06)\end{array}$ & $\begin{array}{c}-1.87 \mathrm{e}-06^{* * *} \\
(6.71 \mathrm{e}-06)\end{array}$ \\
\hline Implied wage-spread elasticity & {$[-.002]$} & {$[.0009]$} & {$[-.001]$} \\
\hline Observations & $1,484,243$ & $1,484,243$ & $1,484,243$ \\
\hline$R^{2}$ within & .073 & .029 & .085 \\
\hline$F$ statistic & 115.68 & 72.61 & 167.64 \\
\hline P-value & .000 & .000 & .000 \\
\hline TOBIT RANDOM EFFECTS & & & \\
\hline Firm labour productivity (log) & $\begin{array}{l}.006^{* * *} \\
(.0002)\end{array}$ & $\begin{array}{l}.015^{* * *} \\
(.0003)\end{array}$ & $\begin{array}{l}.018^{* * *} \\
(.0002)\end{array}$ \\
\hline Average productivity & $\begin{array}{l}.0004^{* * *} \\
(4.25 \mathrm{e}-06)\end{array}$ & $\begin{array}{c}-.0001^{* * *} \\
(6.17 \mathrm{e}-06)\end{array}$ & $\begin{array}{l}.0002^{* * *} \\
(5.41 \mathrm{e}-06)\end{array}$ \\
\hline Productivity spread (SD) & $\begin{array}{c}-7.98 \mathrm{e}-06^{* * *} \\
(1.42 \mathrm{e}-07)\end{array}$ & $\begin{array}{c}2.74 \mathrm{e}-06^{* * *} \\
(2.08 \mathrm{e}-07)\end{array}$ & $\begin{array}{c}-3.28 \mathrm{e}-06^{* * *} \\
(1.80 \mathrm{e}-07)\end{array}$ \\
\hline Implied wage-spread elasticity & {$[-.004]$} & {$[.001]$} & {$[-.002]$} \\
\hline Observations & $1,484,243$ & $1,484,243$ & $1,484,243$ \\
\hline Log likelihood & 31,342 & $-49,687$ & $-320,564$ \\
\hline$\chi^{2}$ statistic & 515,603 & 133,877 & 514,277 \\
\hline P-value & .000 & .000 & .000 \\
\hline Sigma-u & .184 & .236 & .267 \\
\hline
\end{tabular}

Using the SD as an alternative measure of the productive spread, we obtain further confirmation

\footnotetext{
${ }^{22}$ Full results are available from the authors upon request.
} 
of our theoretical predictions. The major difference is the size of the effects, which are now much smaller than the ones initially found. ${ }^{23}$ However, it is worth noticing that the mean and the volatility of this series are also much higher, as suggested by the summary statistics in Table 1 . This means that, when compared to the MAD, the same relative change in the productivity spread measured by the SD implies a much larger absolute variation. Thus, some caution is needed when comparing the results using these two different measures of firm heterogeneity.

As a further robustness check, we have also used weighted measures for the first and second moments of the firms productivity distribution. To do so, we compute the mean and the spread of firm productivity within each collective agreement using the information on firm sales per employee at the worker-level. The resulting measures are, therefore, weighted by the number of workers in each firm. The results not shown (but available upon request) are qualitatively similar.

\subsection{Alternative measure of the wage cushion}

So far, we have assumed that the wage cushion in (24) is fully driven by firm-specific arrangements following industry-wide collective bargaining. As noted by Cardoso and Portugal (2005), however, some industry agreements also include clauses on tenured-related payments. In such cases, the central union might have some direct influence on the wage cushion defined in (24), thereby challenging our interpretation of the econometric results. To address this concern, we follow Cardoso and Portugal and consider the wage cushion in base wages only. In other words, we exclude tenurerelated and other regular components of pay from actual paid wages when computing the wage cushion. The regression results for this alternative measure are presented in Table 5.

Table 5: Heterogeneity and wage cushion

\begin{tabular}{lcc}
\hline \hline Variable & FIXED EFFECTS & TOBIT RANDOM EFFECTS \\
\hline Firm productivity $(\log )$ & $.005^{* * *}$ & $.022^{* * *}$ \\
& $(.0006)$ & $(.0003)$ \\
Average productivity & $-.0007^{* * *}$ & $-.0009^{* * *}$ \\
& $(.0001)$ & $.00002)$ \\
Productivity spread (MAD) & $.0004^{* * *}$ & $.0005^{* * *}$ \\
& $(.00006)$ & $(.00001)$ \\
Implied wage-spread elasticity & {$[.027]$} & {$[.037]$} \\
Observations & $1,484,243$ & $1,484,243$ \\
$R^{2}$ within/Log likelihood & .021 & $-637,561$ \\
$F$ statistic/ $\chi^{2}$ statistic & 43.40 & 113,036 \\
P-value & .000 & .000 \\
\hline
\end{tabular}

\footnotetext{
${ }^{23}$ The only qualitative difference is that the effect of heterogeneity on the wage cushion is not statistically significant in the fixed effects model.
} 
... table 5 continued

\begin{tabular}{lcc}
\hline \hline Variable & FIXED EFFECTS & TOBIT RANDOM EFFECTS \\
\hline & & \\
Firm productivity (log) & $.005^{* * *}$ & $.021^{* * *}$ \\
& $(.0006)$ & $(.0003)$ \\
Average productivity & $-.0001^{* * *}$ & $-.0002^{* * *}$ \\
& $(.00004)$ & $(8.10 \mathrm{e}-06)$ \\
Productivity spread (SD) & $.000002^{*}$ & $5.65 \mathrm{e}-06^{* * *}$ \\
& $(1.14 \mathrm{e}-06)$ & $(2.59 \mathrm{e}-07)$ \\
Implied wage-spread elasticity & {$[.001]$} & {$[.003]$} \\
Observations & $1,484,243$ & $1,484,243$ \\
$R^{2}$ within $/$ Log likelihood & .020 & $-638,100$ \\
$F$ statistic/ $\chi^{2}$ statistic & 41.66 & 111,915 \\
P-value & .000 & .000 \\
\hline \hline
\end{tabular}

Notes: Significance levels: $\quad *: 10 \% \quad * *: 5 \% \quad * * *: 1 \%$. All regressions include industry, region and time effects. Robust standard errors are clustered by collective wage agreement and year in the fixed effects model.

We find that the relationship between the various measures of firm heterogeneity considered earlier and the wage cushion remains positive and statistically significant in all specifications. Moreover, in either model - fixed effect or Tobit random effect - the magnitude of the effects for this alternative measure of the wage cushion is similar (slightly larger).

\section{Concluding remarks}

If actual paid wages result from a combination of industry-wide and firm-specific wage setting as in most countries with a certain degree of union centralisation - what determines the relative importance of the two levels in such a two-tiered wage setting system? In this paper we have offered one particular contribution to answering this question, by focusing on the role of firm heterogeneity within industries. While it is intuitively plausible that firm heterogeneity should play a role in determining the relationship between centralised and decentralised wage setting, the present paper is, to the best of our knowledge, the first attempt to analyse - theoretically and empirically - this particular relationship.

Our results are clear and consistent. There is a systematic correlation between firm heterogeneity and wages set at the two stages. In more heterogeneous industries, the industry wage floor is lower, while the average wage cushion is higher. Furthermore, the former effect dominates the latter, implying that actual paid wages are lower, all else equal, in more heterogeneous industries. The mechanisms behind these relationships are explained by a theoretical model of a unionised Cournot 
oligopoly with firm productivity heterogeneity and a two-tiered wage setting system. The relationships are then empirically confirmed by using a panel dataset covering virtually all workers, firms and collective bargaining agreements of the Portuguese private sector for the period 1991-2000, and the results are robust to different specifications and heterogeneity measures.

By way of conclusion, it should be stressed that in this paper we have only focused on one particular factor - firm heterogeneity - in explaining the discrepancy between centrally bargained and actually paid wages. Although we have shown that this is a significant part of the explanation, it is clearly not the whole explanation. In particular, it would be interesting to explore also the role of worker heterogeneity. While worker attributes obviously affect wages set in each stage, it is tempting to speculate that worker heterogeneity per se could potentially play a role in explaining the relationship between bargained and actual paid wages. This is, however, left for future research. 


\section{Appendix}

\section{A.1. Definition of skill groups}

In the econometric analysis, we include a group of dummy variables to control for the skill level associated with the worker's occupation, as defined in the ISCO- 88 classification. Table A.1 presents the definition of skill groups.

Table A.1. Description of ISCO skills

\begin{tabular}{|c|c|c|}
\hline 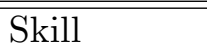 & Description & "ISCO Major group \\
\hline Skill level 1 & $\begin{array}{l}\text { Competence associated with general } \\
\text { education usually acquired by com- } \\
\text { pletion of compulsory education. }\end{array}$ & (9) Elementary occupations \\
\hline Skill level 2 & $\begin{array}{l}\text { Requires knowledge as for first skill } \\
\text { level, but typically a longer period of } \\
\text { worker-related training or work ex- } \\
\text { perience. }\end{array}$ & $\begin{array}{l}\text { (4) Clerks; (5) Service workers and } \\
\text { shop and market sales workers; }(6) \\
\text { Skilled agriculture and fishery; }(7) \\
\text { Craft and related workers; (8) Plant } \\
\text { and machine operators and assem- } \\
\text { blers }\end{array}$ \\
\hline Skill level 3 & $\begin{array}{l}\text { Requires a body of knowledge as- } \\
\text { sociated with a period of post- } \\
\text { compulsory education but not to de- } \\
\text { gree level. }\end{array}$ & $\begin{array}{l}\text { (3) Technicians and associate pro- } \\
\text { fessionals }\end{array}$ \\
\hline Skill level 4 & $\begin{array}{l}\text { Normally requires a degree or an } \\
\text { equivalent period of relevant work } \\
\text { experience. }\end{array}$ & $\begin{array}{l}\text { (1) Legislators, senior officials and } \\
\text { managers; (2) Professionals }\end{array}$ \\
\hline
\end{tabular}

\section{A.2. Longitudinal linked employer-employee dataset}

\section{A.2.1. Checks on the consistency of data}

After deleting observations for which the worker identification code was invalid or missing, the initial worker panel comprises 4,983,541 workers and 20,897,780 worker-year observations. Inconsistencies were identified if the worker gender or date of birth was reported changing, or the highest schooling level achieved by a worker was reported decreasing over time. In line with Cardoso (2006), the following procedures were implemented to correct such inconsistencies:

(i) Dealing with missing values when reported data for the rest of the periods was absolutely consistent. Whenever the gender, age or education of an individual was reported in a consistent way but missing in some year(s), we have assigned the reported value to the missing observation. These corrections affected 0.00 percent, 1.78 percent and 0.89 percent of the observations in the initial panel, respectively, for gender, age and schooling. 
(ii) Dealing with inconsistent data on gender, birth date or schooling over time. When information was reported inconsistently over time, the information reported more than half of the times has been taken as the correct one. Inconsistent values on gender were replaced, after checking that the date of birth in the observation to be corrected was the same as the most frequently reported date of birth for that worker. A similar procedure was followed for the birth date and education, replacing inconsistent values with that reported more than half of the times. According to this procedure, 0.84 percent, 2.54 percent and 5.65 percent of the observations in the initial panel have been corrected for gender, birth date and education, respectively. All information on a worker was dropped in case of remaining inconsistencies after the implementation of the previously described corrections. This led to dropping 8.77 percent of the observations in the initial panel due to inconsistencies for gender, 0.18 percent for age and 0.93 percent for education.

(iii) Deleting data on workers with remaining missing data on gender, age or schooling. Workers with missing data after the implementation of the previous corrections were dropped. This led to dropping 0.18 percent of the observations in the initial panel due to missing age and 0.93 percent due to missing data on schooling. The checked panel included 17,366,086 worker-year observations and 3,062,216 workers.

\section{A.2.2. Constraints imposed}

(i) Keeping full time workers, aged between 16 and 65 years old, earning at least the national minimum wage. Only full-time workers working at least 25 hours a week, aged between 16 and 65 years old, earning at least the national minimum wage were kept for the analysis (the national minimum wage constraint might imply dropping workers in particular categories, such as apprentices and workers aged less than 18 years old). These restrictions led to dropping, respectively, 19.15, 2.33 and 4.04 percent of the observations in the checked panel.

(ii) Keeping job categories with at least 50 workers and agreements with at least 1,000 workers. As in Cardoso and Portugal (2005), because we are computing the contractual wage as the mode of the distribution of base wages for each job category within each collective agreement, for each year we have kept categories with at least 50 workers and agreements with at least 1,000 workers. These restrictions led to dropping 9.08 percent and 1.16 percent of the checked panel, respectively.

(iii) Keeping workers covered by sectorial agreements. After the previous constraints, 87.76 percent of the workers and 83.6 percent of the worker-year observations are covered by sectorial agreements, which are kept for the analysis.

(iv) Keeping observations from manufacturing. After the previous constraints, the worker panel includes 8,988,169 worker-year observations and 2,209,338 workers. We then merged the worker data with firms operating in manufacturing and services. This yields a worker-firm panel with 
information on $8,348,861$ worker-year observations, 2,049,522 workers and 251,945 firms. After further dropping the observations for which data on the independent variables were missing, and keeping data only from mainland Portugal, the final worker-firm panel gathers information on 1,886,703 workers, 216,681 firms and 198 sectorial agreements for the years 1991 to 2000, yielding a total of 7,420,900 observations. Table A.2 presents the share of observations per skill group, region and year.

Table A.2. Summary statistics

\begin{tabular}{llrr}
\hline \hline & & Population & Sample \\
\hline Skill & 1 & 17.22 & 17.22 \\
& 2 & 72.06 & 71.11 \\
& 3 & 7.43 & 7.37 \\
& 4 & 3.29 & 3.31 \\
Region & North & & \\
& Center & 7.79 & 7.78 \\
& Lisbon and Tejo Valley & 10.72 & 10.69 \\
& Alentejo & 39.12 & 39.09 \\
& Algarve & 2.21 & 2.20 \\
& & 2.70 & 2.65 \\
& 1991 & & \\
& 1992 & 7.79 & 7.78 \\
& 1993 & 8.33 & 8.32 \\
& 1994 & 8.41 & 8.42 \\
& 1995 & 8.39 & 8.40 \\
& 1996 & 10.12 & 10.07 \\
& 1997 & 10.55 & 10.54 \\
& 1998 & 11.47 & 11.49 \\
& 1999 & 11.01 & 11.01 \\
& 2000 & 11.95 & 11.98 \\
& & 11.98 & 12.00 \\
& & $7,420,900$ & 1,484243 \\
\hline \hline
\end{tabular}




\section{References}

[1] Akerlof, G., Yellen, J. (1990). 'The Fair Wage-Effort Hypothesis and Unemployment.' Quarterly Journal of Economics, vol. 105, pp. 255-283.

[2] Bastos, P. and Kreickemeier, U. (2007). 'Unions, Competition and International Trade in General Equilibrium.' University of Nottingham, mimeo.

[3] Butter, F. and Eppink, F. (2003). 'The Influence of Labour Flows on Wage Drift: An Empirical Analysis for The Netherlands.' Applied Economics Letters, vol. 10, pp. 139-142.

[4] Calmfors, L. (1990). Wage Formation and Macroeconomic Policy in Nordic Countries. Oxford: Oxford Economic Press.

[5] Cardoso, A. (2006). 'Wage Mobility: Do Institutions Make a Difference?'Labour Economics, vol. 13, pp. 387-404.

[6] Cardoso, A. and Portugal, P. (2005). 'Contractual Wages and the Wage Cushion under Different Bargaining Settings.' Journal of Labor Economics, vol. 23, pp. 879-902.

[7] Danthine, J.P. and Kurmann, A. (2006). 'Efficiency wages revisited: The internal reference perspective.' Economics Letters, vol. 90, pp. 278-284.

[8] Davis, D. and Harrigan, J. (2007). 'Good Jobs, Bad Jobs and Trade Liberalization.' NBER Working Paper No. 13139, National Bureau of Economic Research.

[9] Dhillon, A. and Petrakis, E. (2002). 'A Generalised Wage Rigidity Result'. International Journal of Industrial Organization, vol. 20, pp. 285-311.

[10] Dolado, J., Felgueroso, F. and Jimeno, J. (1997). 'The Effects of Minimum Bargained Wages on Earnings: Evidence from Spain.' European Economic Review, vol. 41, pp. 713-721.

[11] Dowrick, S. (1989). 'Union-Oligopoly Bargaining.' Economic Journal, vol. 99, Vol. 99, pp. 1123-1142.

[12] Egger, H. and Kreickemeier, U. (2008). 'Firm Heterogeneity and the Labour Market Effects of Trade Liberalisation.' International Economic Review, forthcoming.

[13] Flanagan, R. (1999). 'Macroeconomic Performance and Collective Bargaining.' Journal of Economic Literature, vol. 37, pp. 1150-1175.

[14] Franco, F. and Philippon, T. (2007). 'Firms and Aggregate Dynamics.' Review of Economics and Statistics, vol. 89, pp. 587-600. 
[15] Hibbs, D. and Locking, H. (1996). 'Wage Compression, Wage Drift and Wage Inflation in Sweden.' Labour Economics, vol. 3, pp. 109-141.

[16] Holden, S. (1988). 'Local and Central Wage Bargaining.' Scandinavian Journal of Economics, vol. 90, pp. 93-99.

[17] Holden, S. (1989). 'Wage Drift and Bargaining: Evidence from Norway.' Economica, vol. 56, pp. 419-432.

[18] Holden, S. (1998). 'Wage Drift and the Relevance of Centralised Wage Setting.' Scandinavian Journal of Economics, vol. 100, pp. 711-731.

[19] Hübler, O. and Jirjahn, U. (2003). 'Work Councils and Collective Bargaining in Germany: The Impact on Productivity and Wages.' Scottish Journal of Political Economy, vol. 50, pp. 471-491.

[20] ILO (1990). ISCO-88: International Standard Classification of Occupations, Geneva: International Labour Office.

[21] Melitz, M. (2003). 'The Impact of Trade on Intra-Industry Realocation and Aggregate Industry Productivity.' Econometrica, vol. 71, pp. 1695-1725.

[22] Muysken, J. and van Veen, T. (1996). 'Efficiency Wages and Local Wage Bargaining.' Scandinavian Journal of Economics, vol. 98, pp. 119-127.

[23] Ordine, P. (1996). 'Wage Drift and the Minimum Contractual Wage: Theoretical Interrelationship and Empirical Evidence for Italy.' Labour Economics, vol. 2, 335-357.

[24] OECD (2004). 'Wage-setting Institutions and Outcomes.' in OECD Employment Outlook 2004 Edition (eds.), Paris: Organisation for Economic Co-operation and Development. 